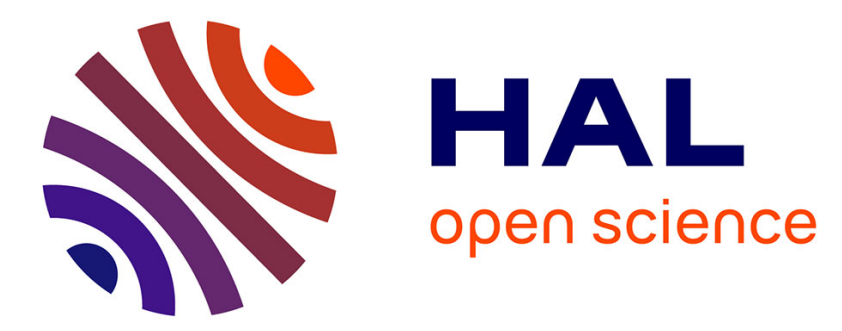

\title{
Discovery of Lower Cretaceous synmetamorphic thrust tectonics in French Lesser Antilles (La Désirade Island, Guadeloupe): Implications for Caribbean geodynamics
}

\author{
M. Corsini, J.-M. Lardeaux, C. Verati, E. Voitus, M. Balagne
}

\section{- To cite this version:}

M. Corsini, J.-M. Lardeaux, C. Verati, E. Voitus, M. Balagne. Discovery of Lower Cretaceous synmetamorphic thrust tectonics in French Lesser Antilles (La Désirade Island, Guadeloupe): Implications for Caribbean geodynamics. Tectonics, 2011, 30, pp.TC4005. 10.1029/2011TC002875 . hal-00620555

\section{HAL Id: hal-00620555 \\ https://hal.science/hal-00620555}

Submitted on 25 Oct 2021

HAL is a multi-disciplinary open access archive for the deposit and dissemination of scientific research documents, whether they are published or not. The documents may come from teaching and research institutions in France or abroad, or from public or private research centers.
L'archive ouverte pluridisciplinaire HAL, est destinée au dépôt et à la diffusion de documents scientifiques de niveau recherche, publiés ou non, émanant des établissements d'enseignement et de recherche français ou étrangers, des laboratoires publics ou privés.

$$
\text { Copyright }
$$




\title{
Discovery of Lower Cretaceous synmetamorphic thrust tectonics in French Lesser Antilles (La Désirade Island, Guadeloupe): Implications for Caribbean geodynamics
}

\author{
M. Corsini, ${ }^{1}$ J. M. Lardeaux, ${ }^{1}$ C. Verati, ${ }^{1}$ E. Voitus, ${ }^{2}$ and M. Balagne ${ }^{3}$ \\ Received 22 January 2011; revised 29 March 2011; accepted 25 April 2011; published 27 July 2011.
}

[1] Located east of Guadeloupe, the island of La Désirade exhibits the oldest rocks of the Lesser Antilles arc and the eastern Caribbean plate. An old magmatic basement is composed of (1) late Jurassic ophiolitic complex with meta-basaltic pillow lavas and interbedded radiolarites, (2) acid igneous complex comprising meta-quartz-diorite and meta-rhyolitic lavas flows, and (3) meta-diabasic/microdioritic dyke swarm complex. We present and discuss the discovery of synmetamorphic thrust tectonics in this island.

Based on detailed structural analysis we evidenced two main compressive events. The first event (D1) is characterized by pervasive folding associated with thrust development. In the northeastern part of the island, a major thrust fault, the Grand Abaque Thrust, has been discovered which displaces for several kilometers the acid igneous complex onto the ophiolitic unit. The second deformation event (D2) is featured by a main pervasive cleavage S2 observed at the regional scale associated with upright folding (F2) and by the development of two sets of conjugated steeply dipping strike-slip shear zones, dextral $130^{\circ} \mathrm{N}$ and sinistral $20^{\circ} \mathrm{N}$ striking, respectively. Microstructural observations indicate that Greenschist facies metamorphism is clearly contemporaneous with the development of D1 and D2 superimposed tectonic structures. Ar/Ar geochronology was performed on two bulk of adularia minerals sampled in the northeast volcanic complex within a deformed zone related to a D2 event. These analyses yield well-defined and concordant plateau ages at 106.2 $\pm 1.7 \mathrm{Ma}$ and 107.2 $\pm 1.8 \mathrm{Ma}$. Thus, shortening and thickening tectonics occurred during Lower Cretaceous (Albian). In the available framework of Caribbean geodynamics, the synmetamorphic thrust tectonics we discovered in the French Lesser Antilles is related to the collision between an Aptian-Albian oceanic plateau and the Andean-Cordilleran east-dipping subduction zone. Our results support subduction polarity reversal during Lower Cretaceous.

Citation: Corsini, M., J. M. Lardeaux, C. Verati, E. Voitus, and M. Balagne (2011), Discovery of Lower Cretaceous synmetamorphic thrust tectonics in French Lesser Antilles (La Désirade Island, Guadeloupe): Implications for Caribbean geodynamics, Tectonics, 30, TC4005, doi:10.1029/2011TC002875.

\section{Introduction}

[2] Understanding the formation of the Caribbean plate implies to characterize the relative motions of the North American, South American and Farallon plates [Pindell and Dewey, 1982; Burke, 1988; Pindell et al., 1998], but also their interaction with the Caribbean-Colombian Oceanic Plateau (CCOP) [Kerr et al., 1997, 1998], which formed in the Pacific on the Farallon plate since 124 Ma with a major episode at around 94-90 Ma, moved into the proto-Caribbean

\footnotetext{
${ }^{1}$ Université Nice-Sophia Antipolis, UMR Geoazur, Nice, France.

${ }^{2}$ Université Antilles-Guyane, IUFM de Guadeloupe, Abymes, Guadeloupe.

${ }^{3}$ Université Antilles-Guyane, IUT Campus de Saint-Claude, SaintClaude, Guadeloupe.

Copyright 2011 by the American Geophysical Union. 0278-7407/11/2011TC002875
}

seaway between North and South American plates, and consequently encountered the Pacific subduction zone and the related "Great Arc of the Caribbean" [Burke, 1988; Kerr et al., 1999].

[3] Even if the Pacific origin of the Caribbean lithosphere is now widely accepted (see reviews by Kerr et al. [2003] and Pindell and Kennan [2009]), the question of the reversal in subduction polarity from east to west and the role of the CCOP in this subduction "flip" is still a matter of debate in Caribbean geodynamics [Pindell and Kennan, 2009; Hastie and Kerr, 2010].

[4] Since the pioneering works of Fink [1968], Mattinson et al. [1973], Westercamp [1980] and Bouysse et al. [1983], Jurassic oceanic rocks subduction-related magmatic rocks have been identified on the island of La Désirade. The latter, located east of Guadeloupe in the Lesser Antilles (Figures 1 and 2a) and composed of the oldest rocks of the Lesser Antilles arc and the eastern Caribbean plate, is therefore a 


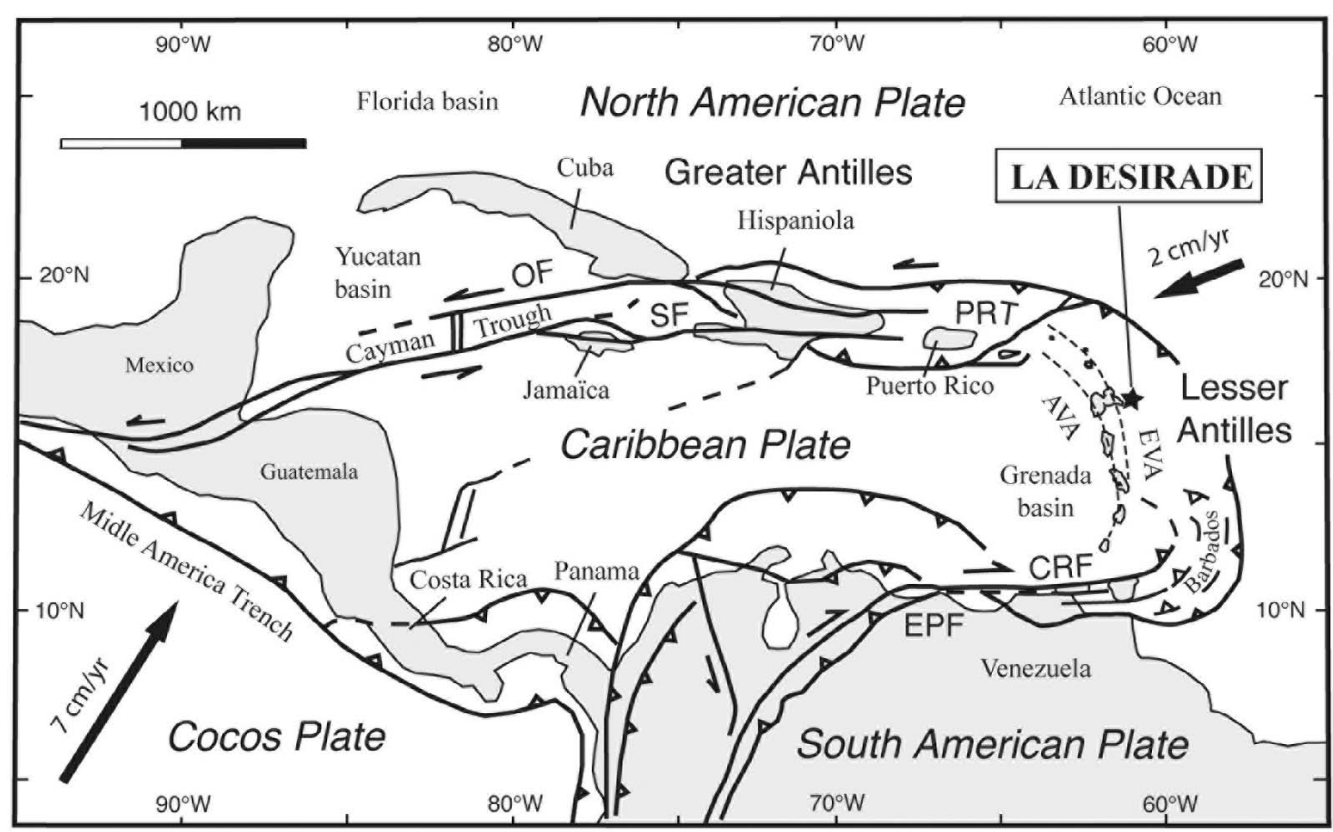

Figure 1. Geodynamic setting of the Caribbean plate with location of Lesser Antilles and La Désirade Island [after Pindell and Kennan, 2009]: EPF, El Pilar Fault; CRF, Central Range Fault; OF, Oriental Fault; PRT, Puerto Rico Trench; SF, Septentrional Fault.

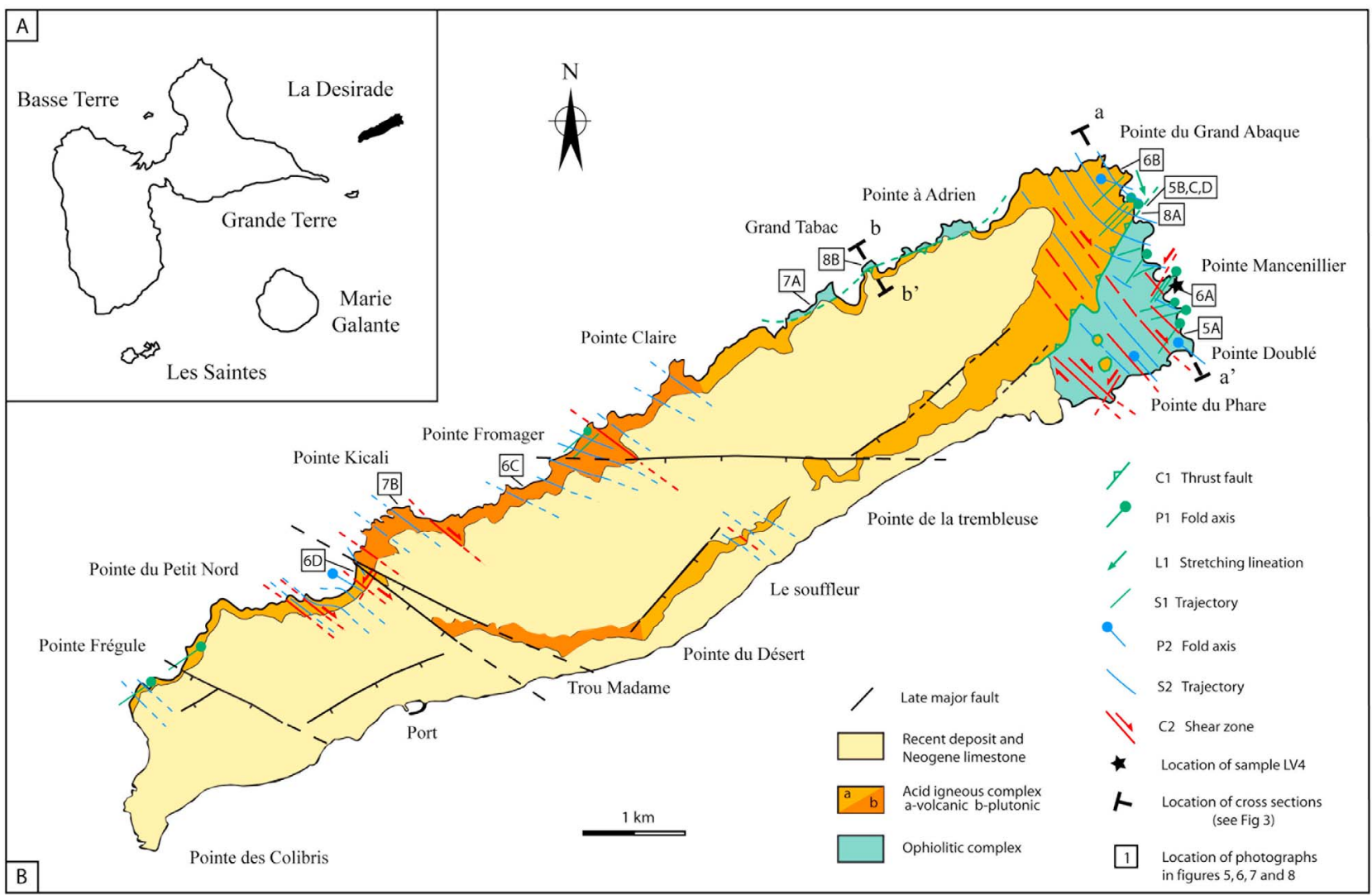

Figure 2. (a) Location of La Désirade Island into the Guadeloupe archipelago and (b) tectonic sketch map of the studied island. 
crucial element for understanding both Caribbean geodynamics and the current tectonic setting of the Lesser Antilles arc. Indeed, the magmatic basement of La Désirade represents the exhumed base of the present-day active Lesser Antilles volcanic arc on which direct information is difficult to acquire.

[5] Moreover, up to now, only recent extension related brittle tectonic structures have been indentified in La Désirade Island [Westercamp, 1980; Feuillet et al., 2001, 2002]. The aims of this study are (1) to present the discovery of synmetamorphic thrust and related folds tectonics in La Désirade island, (2) to date these structures by $\mathrm{Ar} / \mathrm{Ar}$ technique, (3) to interpret this finite strain pattern in the framework of Caribbean geodynamics, and (4) to document a field case which may potentially serve as an analog for future geophysical investigations of the base the Lesser Antilles arc.

\section{Tectonic Setting of the Lesser Antilles Arc in the Caribbean Plate}

[6] The Lesser Antilles arc is located on the eastern margin of the Caribbean plate. In this site, the convergence between Atlantic and Caribbean plates is absorbed by subduction of Atlantic lithosphere under the arc (Figure 1) and the Lesser Antilles arc results from subduction of the North American plate under the Caribbean plate, with an ENE orientation, at rates of about $2 \mathrm{~cm} / \mathrm{yr}$ [Dixon and Mao, 1997; Dixon et al., 1998; DeMets et al., 2000].

[7] The Lesser Antilles arc is parallel to the subduction trench and has a curvature radius of about $450 \mathrm{~km}$. It can be followed from the eastern Venezuela continental margin to the Anegada Passage, which marks the boundary with the Greater Antilles.

[8] The northern and southern Caribbean plate boundaries correspond to two strike-slip systems. To the north, the Caribbean plate is bounded by the Oriental and Septentrional faults and the Puerto Rico trench; while to the south the Caribbean plate is bounded by a dextral strike-slip fault zone, the El Pilar-Central Range fault zone [Jordan, 1975; Adamek et al., 1988; Holcombe et al., 1990; Mascle and Letouzey, 1990; Pindell and Barrett, 1990; Heubeck and Mann, 1991; Mann et al., 1995; Flinch et al., 1999; Weber et al., 2001].

[9] The Lesser Antilles was described as a double arc by Martin-Kaye [1969] and as a multiple arc by Westercamp [1979]. The latter subdivided it into arcs of pre-Miocene, Miocene and post-Miocene to recent ages. Indeed, north of Martinique's Caravelle Peninsula, the arc is divided into two subparallel ridges that splay from the island of Martinique. The western one is composed of a chain of volcanic islands from Grenada through the Grenadines, St. Vincent, St. Lucia, Martinique, Dominica, Les Saintes, Basse-Terre of Guadeloupe, Montserrat, Redonda, Nevis, St. Kitts, St. Eustatius and Saba. It corresponds to the present-day Active Arc or "Volcanic Caribbees" [Bouysse, 1979, 1988; Bouysse et al., 1985; Bouysse and Westercamp, 1990]. The eastern one, $10-50 \mathrm{~km}$ to the east, is composed of islands with a Paleogene basement overlain by uppermost Miocene and Plio-Quaternary coral limestone ("Limestone Caribbees") [Gunn and Roobol, 1976; Andreieff et al., 1981; Davidson et al., 1993]. This extinct volcanic arc is composed of the islands of Sombrero, Anguilla, St. Martin, St. Barthélémy, Antigua, and Grande
Terre of Guadeloupe. Here, Eocene to Oligocene igneous rocks are capped by Miocene and younger limestones [Maury et al., 1990].

[10] The division of the Lesser Antilles arc into a young inner active volcanic arc and an old outer extinct magmatic arc may result from kinematic changes in the subduction process and/or from the attempted subduction of buoyant aseismic ridges, which exist on the North American plate [McCann and Sykes, 1984; Westbrook and McCann, 1986; Bouysse and Westercamp, 1990], beneath the Lesser Antilles arc (see discussion by Bouysse and Westercamp [1990]).

[11] The northern part of the Lesser Antilles arc, in which the island of La Désirade is located, is the site of trench parallel extension, accommodating the oblique convergence between the North American and Caribbean plates [Feuillet et al., 2001, 2002]. Such extension leads the development of active oblique and normal faults crosscutting the northeastern edge of the Caribbean plate. Related arc perpendicular faults affect the outer arc reef platforms of Grande-Terre of Guadeloupe, Marie-Galante, and La Désirade [Feuillet et al., 2002].

\section{Geological Setting of La Désirade Island}

[12] La Désirade is an $11.5 \mathrm{~km}$ long, and roughly $2 \mathrm{~km}$ large, island located to the east of the main island of Guadeloupe standing out in the fore arc of the Lesser Antilles region (Figure 2a). This island presents a narrow WSW-ENE elongated shape and is mostly composed of an old magmatic basement overlain by Pliocene coral limestone [Barrabé, 1953; Fink, 1970; Westercamp, 1980]. The latter forms a narrow, elongated plateau, tilted northward.

[13] Since Fink [1970], Westercamp [1980], Bouysse et al. [1983], and Mattinson et al. [2008], three mains units have been distinguished in La Désirade magmatic basement: (1) a northeast volcanic complex composed of meta-basaltic pillow lavas and interbedded Jurassic-Early Cretaceous radiolarites (La Désirade ophiolitic complex), (2) a Late Jurassic acid igneous complex comprising meta-quartzdiorite (trondhjemite of Mattinson et al. [2008]) and metarhyolitic lavas flows, and (3) a meta-diabasic/microdioritic dyke swarm complex from unknown age (upper metaandesitic group of Westercamp [1980]). As clearly established by Westercamp [1980] through geological mapping of this island, the magmatic rocks have suffered an extensive metamorphic transformation under greenschist facies conditions.

[14] The interpretation of the La Désirade ophiolitic complex was strongly debated and is interpreted as an ophiolitetype oceanic crust [Mattinson et al., 1973, 1980, 2008; Fox and Heezen, 1975; Dinkelman and Brown, 1977, Le Guen de Kerneizon et al., 1979] or a back arc-related pillow basalts [Fink, 1968, 1970, 1972; Bouysse et al., 1983; Maury et al., 1990; Donnelly et al., 1990; Gauchat, 2004; Cordey and Cornée, 2009]. However, an origin at a back-arc spreading ridge has gained increasing favor in the light of recent and detailed geochemical investigations [Neill et al., 2010] on La Désirade magmatic rocks. Geological (pillow lavas, pelagic sedimentation), petrological (abundance of rhyolites and andesites) and geochemical (trace elements patterns) evidences overwhelmingly favor the model of a back-arc basin in a suprasubduction setting. Late Jurassic radiometric 
NNW

SSE
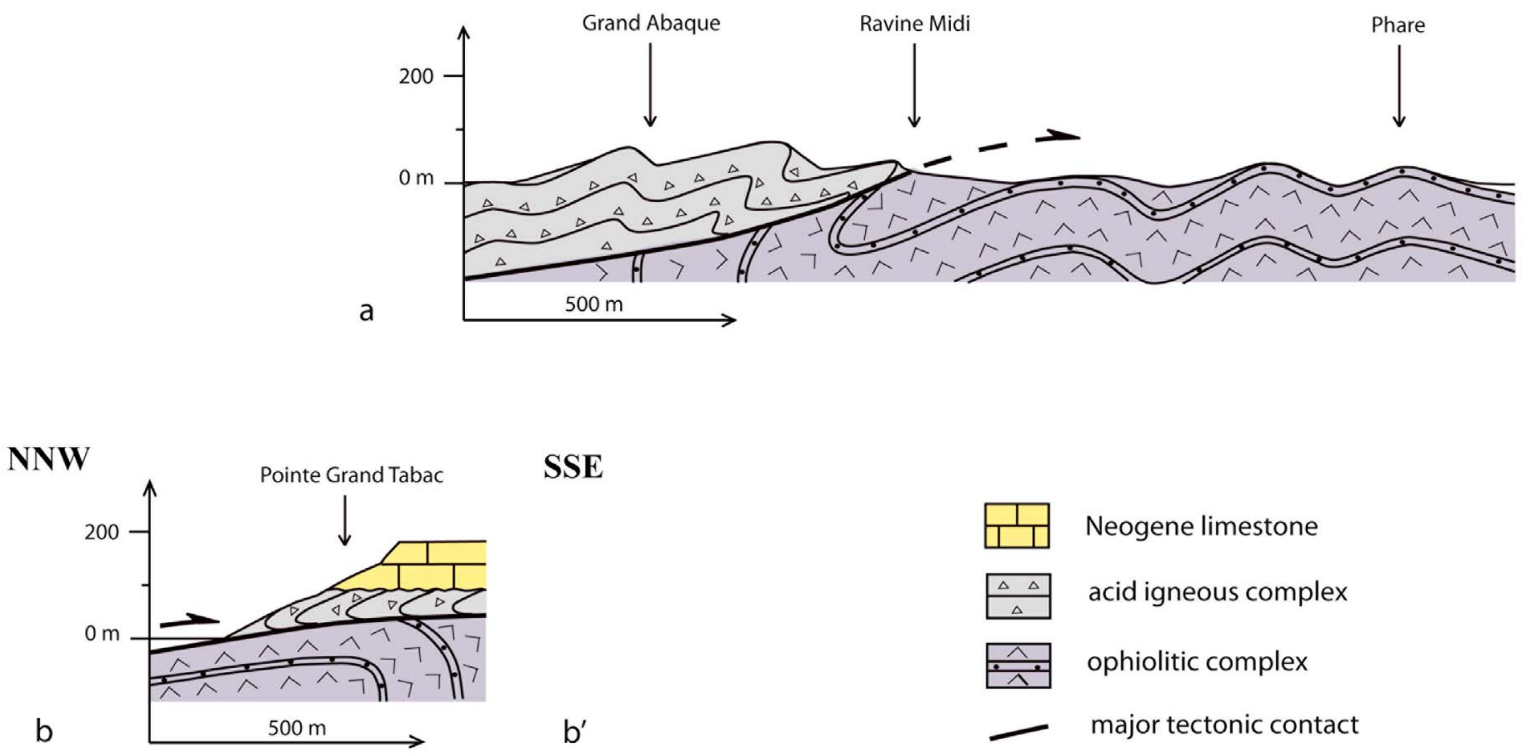

SSE

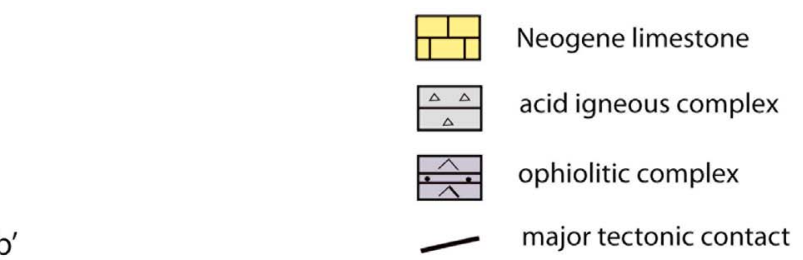

Figure 3. Simplified cross sections in the northeast part of La Désirade Island. See Figure $2 b$ for location.

crystallization ages (around $145 \mathrm{Ma}$ ) have been obtained on zircons from trondhjemite of the acid igneous complex [Mattinson et al., 1973, 1980].

[15] The radiolarian cherts have generated a great deal of attention since the works of Bouysse et al. [1983] and Montgomery et al. [1992]. Recent biostratigraphic studies of Radiolarian bearing cherts show that La Désirade radiolarites are Late Jurassic, ranging from late Kimmeridgian or early Tithonian to early/late Tithonian [Cordey and Cornée, 2009]. Moreover, Mattinson et al. [2008] have redefined a new radiometric age of $143.74+/-0.33 \mathrm{Ma}$ on zircon from the same trondhjemite of Mattinson et al. [1980].

\section{Structural Analysis of La Désirade Basement}

\subsection{Deformation History}

[16] Mapping and detailed structural analysis were carried out in all the units of the magmatic basement of La Désirade
Island to precise geometry, kinematics and relative timing of deformations. Two main finite strain patterns corresponding to a compressional context have been evidenced.

[17] The first event of deformation D1 displays pervasive folding associated with thrust development (Figures 2, 3, and 4). F1 folds display a metric to hectometer wavelength, $30^{\circ} \mathrm{N} \pm 10^{\circ}$ trending steeply dipping axial planes and subhorizontal axes (Figures $4 \mathrm{~b}$ and $5 \mathrm{c}$ ). F1 folds developed axial planar pressure-solution cleavage S1 (Figures 6 and 7), with crystallization of quartz, albite, chlorite and epidote. The D1 deformation event is also characterized by an important thrusting, up to now unknown in this island. The thrust fault, here after called the Grand Abaque Thrust, is observed in the northeastern part of the island, where the acid igneous complex with rhyolitic lavas over thrust onto the ophiolitic unit (Figures 2 and 3). On the available geological map of La Désirade island [Westercamp, 1980; Feuillet et al., 2002] the fault trace appears rectilinear sug-

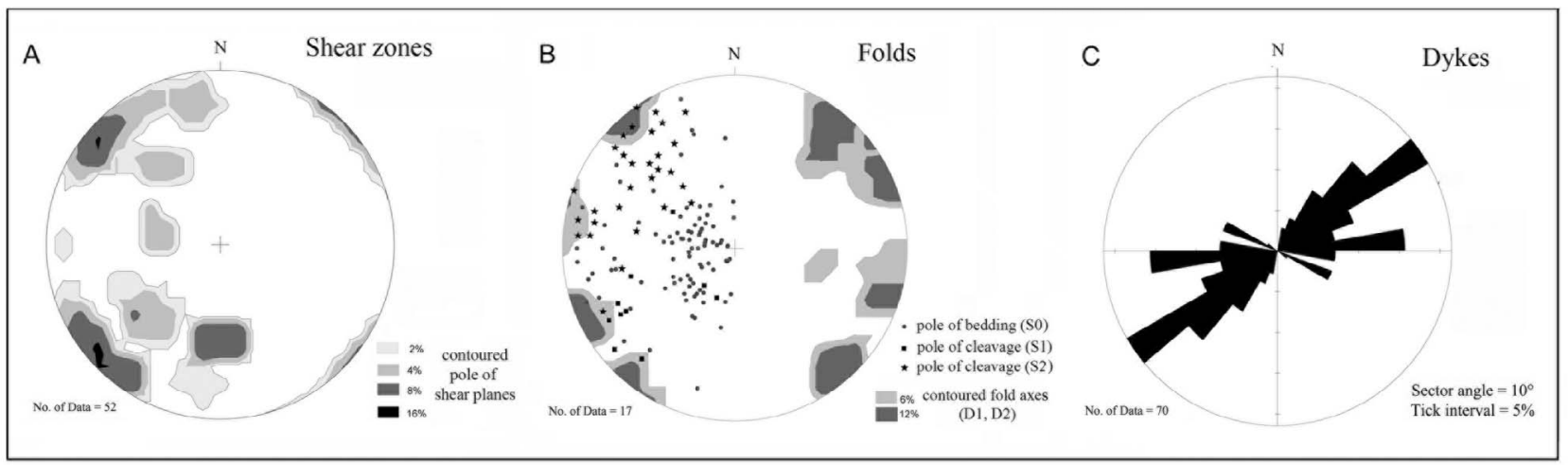

Figure 4. Stereoplots of structural elements (Wulf projection, lower hemisphere): (a) shear zones; (b) S0, S1, S2, and folds axes; and (c) rose diagram showing azimuth of dykes. 

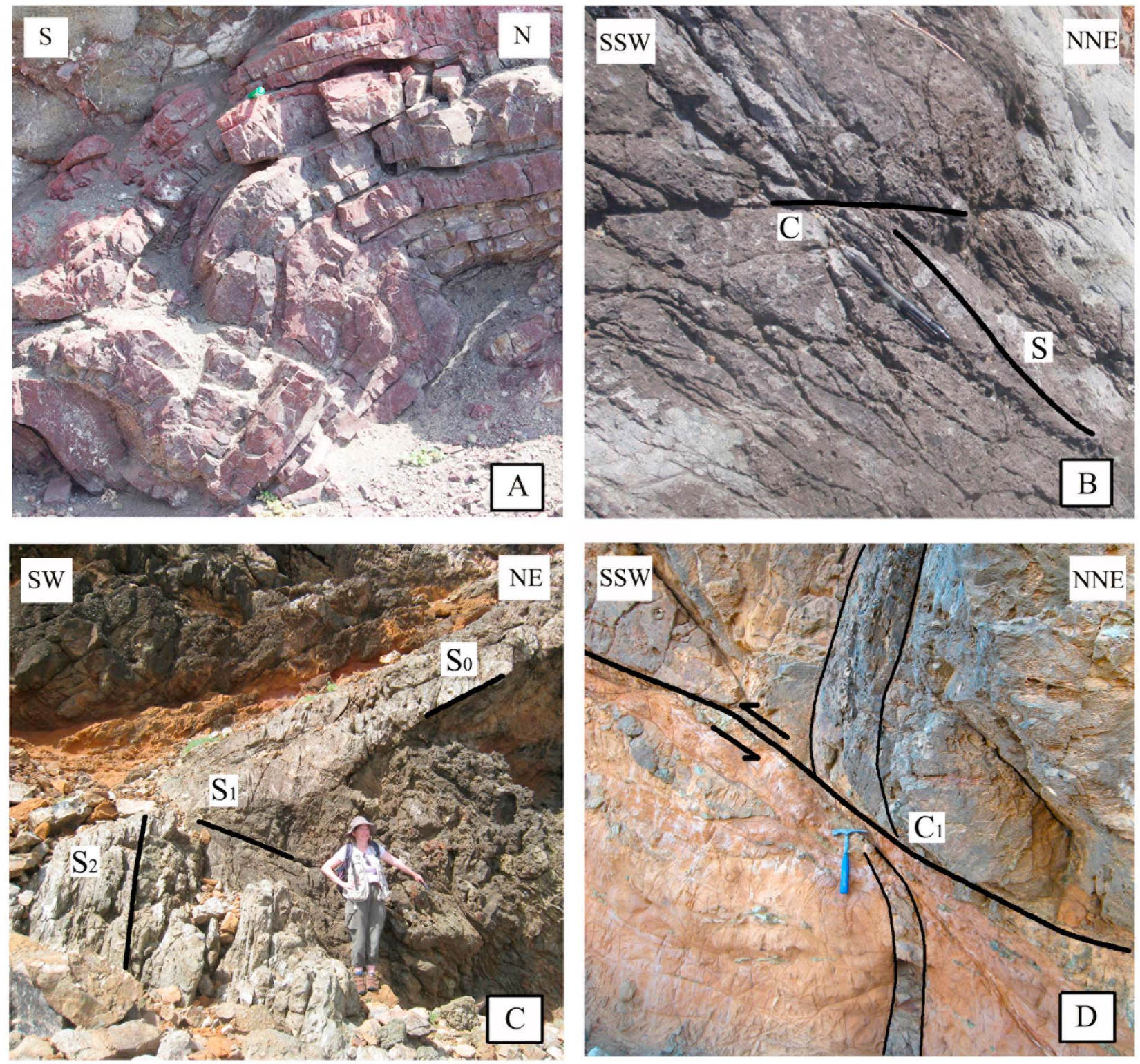

Figure 5. Field photographs of La Désirade significant compressive structures. (a) D1 folding in the cherts from the oceanic unit at the Pointe Doublé. (b) S-C structures in the rhyolitic lavas nearby the Grand Abaque Thrust. (c) Recumbent fold (D1) in the rhyolitic lavas and volcanic breccias cut by a penetrative vertical cleavage (S2) above the Grand Abaque Thrust. (d) Detail of the Grand Abaque Thrust showing mylonitic fabric, asymmetrical lenses, and deformed dykes in the shear zone.

gesting a very steeply dipping, interpreted as a recent normal fault [Feuillet et al., 2002]. However, detailed structural mapping of this area (Figure 2b) shows first the sinuous cartographic trace of a major thrust and second the presence of klippes. These observations attest for a low dip of the fault plane and for its inverse character. The NE-SW striking Grand Abaque Thrust is characterized by a few meter thick Greenschist facies mylonite mainly formed at the expense of metarhyolites and metabasalts. Direction of transport in the shear zone is underlined by a gently northdipping stretching lineation with a $340^{\circ} \mathrm{N} \pm 20^{\circ}$ trending. The most evident kinematic indicators are shear band cleavages, asymmetric folds and sigmoid boudins. All the kinematic indicators show a top to the southeast sense of shear. Identical sense of shear can also be deduced from minor thrust faults observed at the outcrop-scale (Figures $5 \mathrm{~b}$ and $5 \mathrm{~d}$ ). The thrusting zone is also characterized by the abundance of deformed quartz and epidote veins attesting for very strong fluid circulations that produced a complete transformation of the rocks in the Greenschist facies. Approaching the thrust zone, the F1 folds evolve from upright to reversal and recumbent shape showing that strain intensity is inversely proportional to the distance from the contact of the Grand Abaque Thrust (Figures 3 and 8).

[18] The second deformation event (D2) is featured by a main pervasive cleavage $\mathrm{S} 2$ observed at the regional scale 

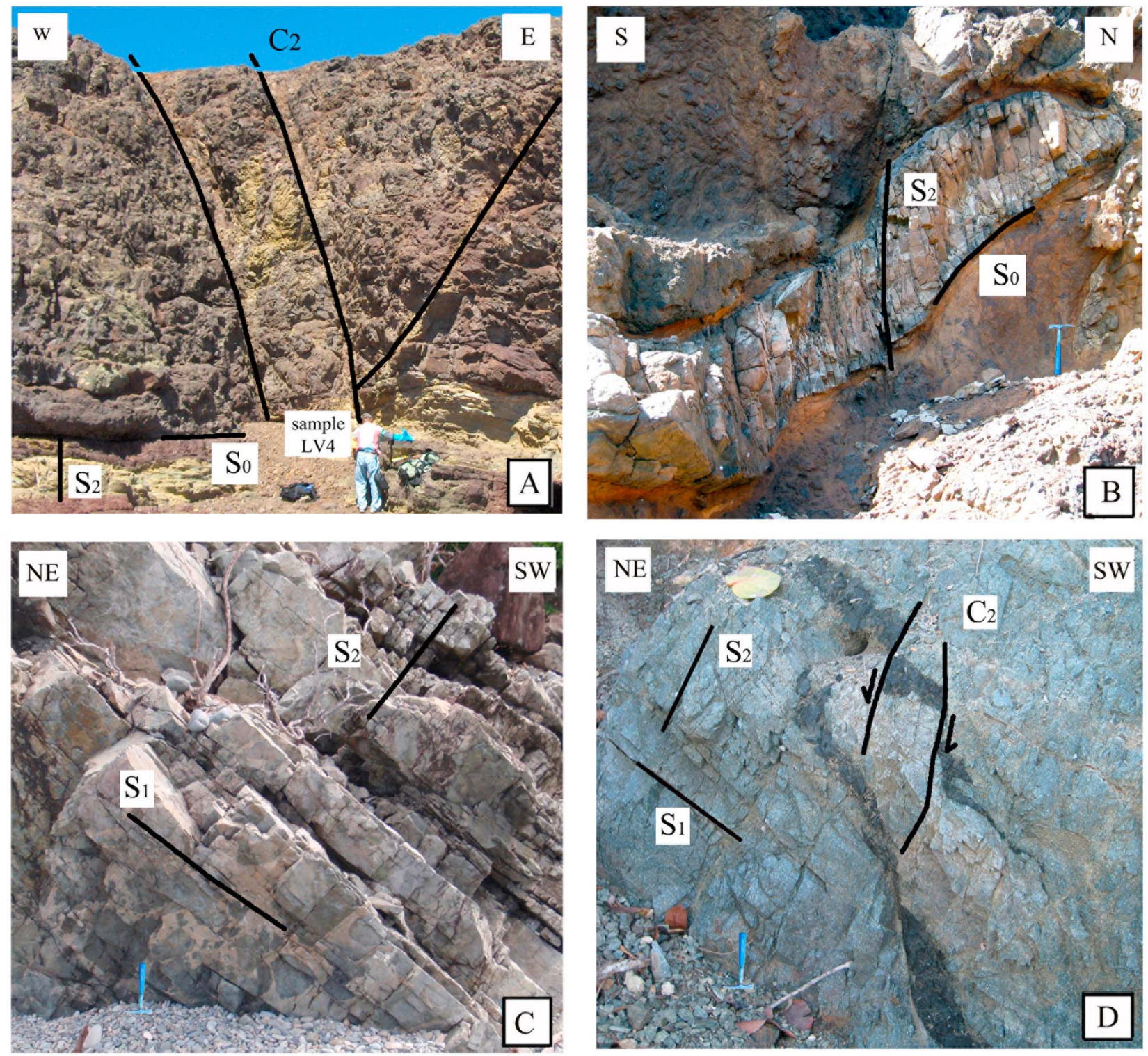

Figure 6. Field photographs of La Désirade significant compressive structures. (a) Conjugated shear zones (D2) affecting meta-basaltic pillow lavas and radiolarites of the oceanic unit in the Pointe Mancenillier, with location of the LV4 sample dated by Ar-Ar radiochronology. (b) Folded (D1) rhyolitic lavas and volcanic breccias, affected by a penetrative S2 schistosity at the Pointe du Grand Abaque. (c) Superposed foliations (S1 and S2) developed in meta-quartz-diorite at the Pointe Fromager. (d) Mafic dykes affected by dextral shear bands at the Pointe du Petit Nord.

associated with upright hectometer wavelength folding (F2) and by the development of narrow shear zones, from centimeters to a few meters thick (Figures 2, 5c, 6, 7b). These shear zones are steeply dipping and record a strike-slip motion under brittle-ductile transition characterized by Greenschist facies mineralogic assemblages (Figure 9). Two sets of conjugated shear zones (Figure 4a) are distinguished: main $\mathrm{N} 130^{\circ} \pm 10^{\circ}$ striking dextral strike-slip shear zones and $20^{\circ} \mathrm{N} \pm 10^{\circ}$ sinistral strike-slip shear zones. The two sets of shear zones are coeval suggesting a nearly northsouth shortening direction in the present-day coordinates of the la Désirade Island. Some of these shear zones corre- spond to the boundaries between different basaltic subunits recognized by Neill et al. [2010] with geochemical criteria.

[19] Structural mapping shows that S2 foliation trajectories (Figures 2 and 4b) draw a typical $\mathrm{S} / \mathrm{C}$ shape indicative of dextral shearing on strike-slip shear zones oriented in a $130^{\circ} \mathrm{N} \pm 10^{\circ}$ strike. Locally the axial trends of $\mathrm{F} 1$ folds are scattered by the D2 deformation event and gradually oriented parallel to the $130^{\circ} \mathrm{N}$ shear zones.

[20] A significant number of diabasic/microdioritic dykes are deformed by both D1 and D2 tectonic events (Figure 4c). Some dykes are sheared (Figure 5d), while others are flat- 

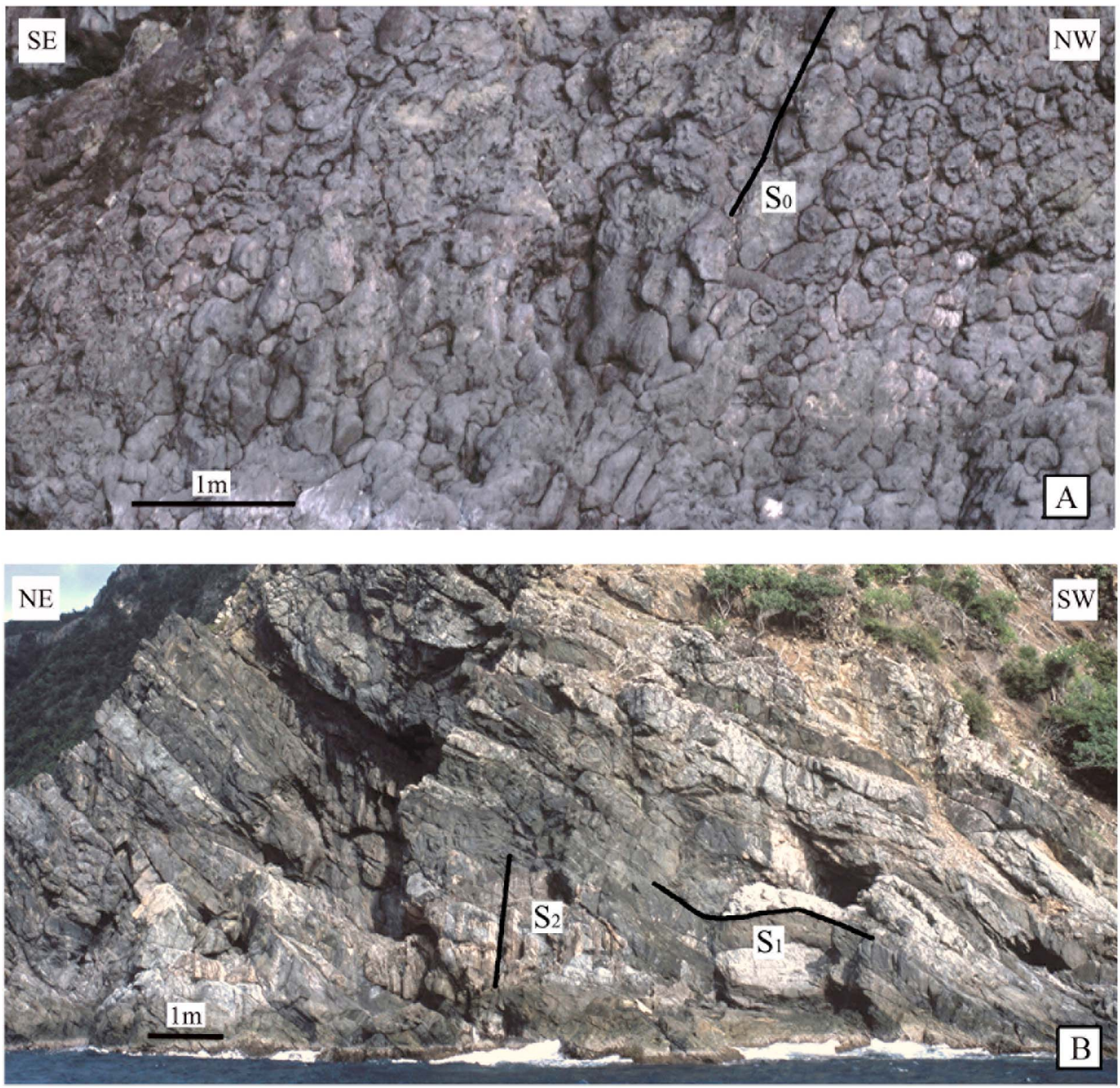

Figure 7. Field photographs of La Désirade significant compressive structures. (a) Basaltic pillow lavas with nearly vertical bedding at the Pointe à Adrien. (b) Folded mafic dykes observed into the acid igneous complex at the Pointe Fromager.

tened or boudinaged (Figures $6 \mathrm{~d}$ and $7 \mathrm{~b}$ ) depending on their initial orientation with respect to finite strain axes. Figure 4 evidences that numerous dykes are parallel to F1 fold axes, as the result of their reorientation during the first deformation event.

\subsection{Deformation and Metamorphism}

[21] The above described deformation history is accomplished under extensive Greenschist facies metamorphic conditions and the following parageneses have been recognized (Figure 9).

[22] 1. In meta-pillowed basalts from the ophiolitic complex (Figure 9a) the observed association is composed of: albite + chlorite + clinozoïsite + quartz + actinolite + calcite +/- sphene +/- stilpnomelane +/- ankerite +/hematite $+/-$ chalcopyrite. In a restricted number of thin sections, we observed also the development of cummingtonite at the expense of magmatic pyroxenes and olivines. Frequently clinozoïsite grains are rimmed or partly replaced by pistacite. These minerals underline both S1 and S2 schistosity planes and related mylonitic bands. Syntectonic veins are filled with quartz and calcite fibbers, albite, chlorite and hematite. In meter to decameter-scale faults zones, the metabasalts are seriously transformed into hydrothermalized breccias in which occurs an association of albite + quartz + chlorite + prehnite $+/-$ laumontite. The latter indicates a late metamorphic evolution under very low grade facies (i.e., Prehnite-Actinolite and Zeolite metamorphic facies). 

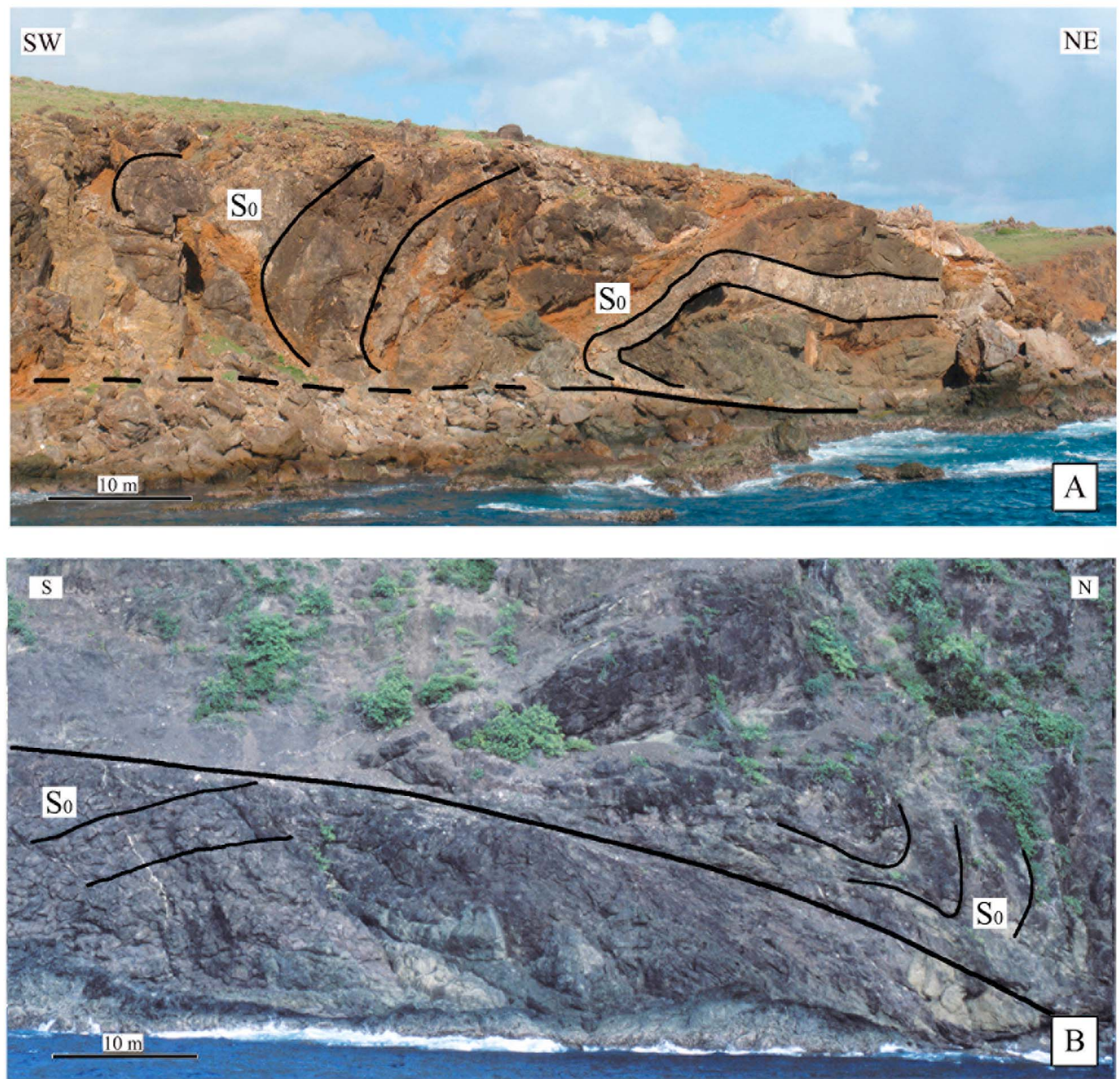

Figure 8. Field photographs of La Désirade significant compressive structures. (a) Overview of the Grand Abaque Thrust separating the acid igneous complex above from the ophiolitic complex at the Baie du Grand Abaque. (b) Overview of the Grand Abaque Thrust at Pointe Grand Tabac.

[23] 2. In the meta-diabasic/microdioritic dykes (Figure 9b), we observed the widespread development of chlorite + albite + pistacite + calcite. In some outcrops, where the dykes are strongly deformed by ductile to semibrittle discrete shear zones (Figure 6a) or are folded or faulted, the magmatic mineralogy is completely replaced by the Greenschist facies metamorphic association.

[24] 3. In meta-rhyolites from the acid igneous complex (Figure 9c) the observed metamorphic mineralogy is an association of quartz + albite + clinozoïsite $+/-$ stilpnomelane. These minerals are observed in pressure solution cleavages as well as in veins or microfractures crosscutting S1 and S2 planes. In this lithology, numerous brittle faults developed at the centimeter to meter scale, which contains late crystal- lizations of prehnite, laumontite and zeolites. Here also, these late phases reflect the progressive cooling of La Désirade basement rocks from Greenschist to Zeolite facies conditions thought time.

[25] 4. In meta-diorites or meta-trondhjemites (Figure 9d), an association of actinolite + albite + calcite replaces magmatic hornblendes and/or pyroxenes, and the widespread development of clinozoïsite + quartz + chlorite + albite records the Greenschist facies metamorphism. In some samples, we observed also sphene, numerous chalcopyrites and vermiculite replacing probably magmatic phases.

[26] 5. In mylonitic rhyolites (Figures 9e and 9f) observed in the Grand Abaque Thrust, the preferred shape orientation is marked by elongation of quartz porphyroclasts and 

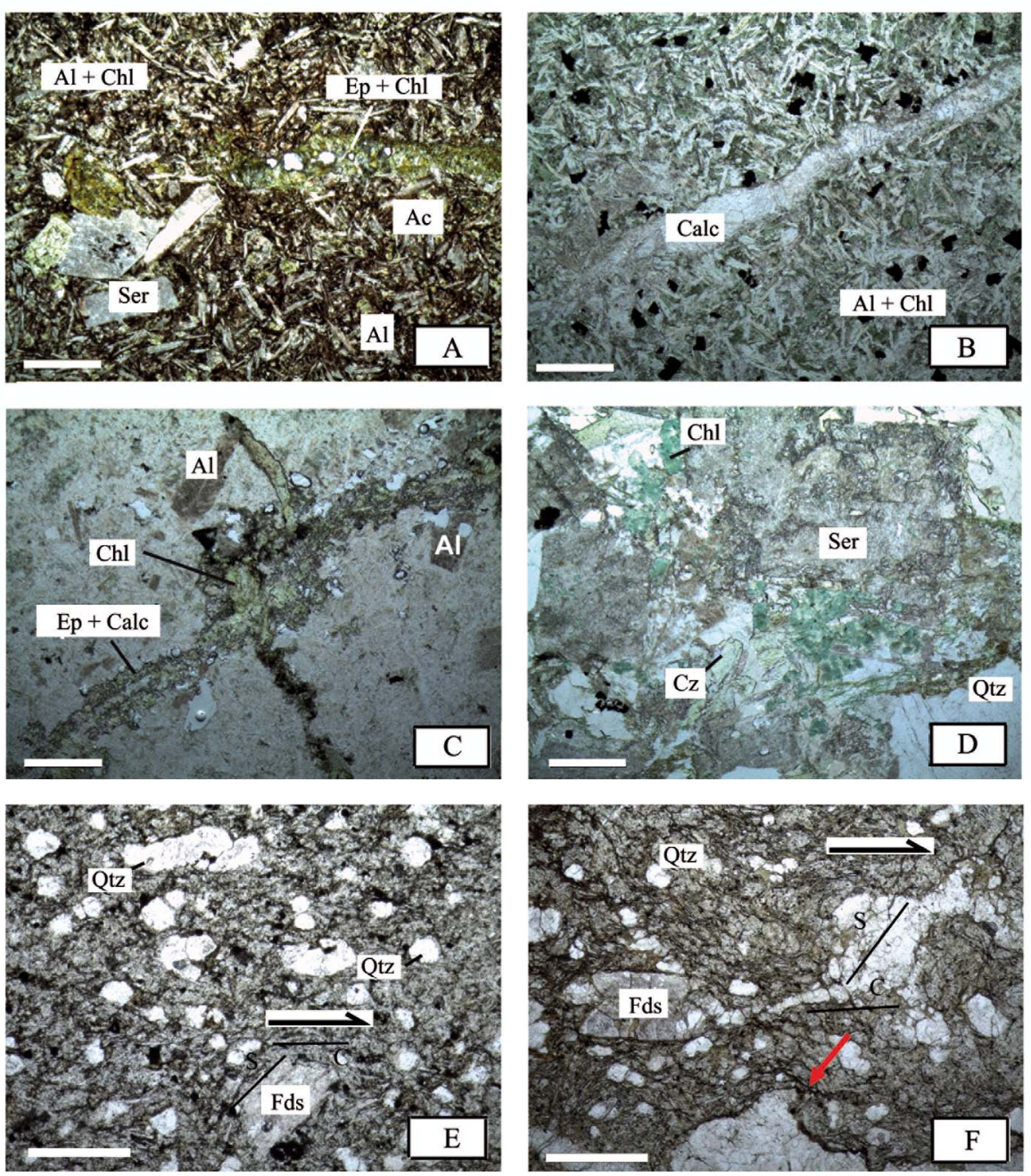

Figure 9. Microphotographs showing the Greenschist facies metamorphic and mylonitic assemblages: (a) meta-pillowed basalts (sample LV5), (b) dyke (sample MV8), (c) meta-rhyolitic complex (sample LV9), (d) meta-trondjhemitic complex (sample LVC06-14), and (e and f) mylonitized rhyolite in the Grand Abaque Thrust. Ser, sericitized plagioclase; Ac, actinolite; Ep, epidote (cz, clinozoïzite); Chl, chlorite; Qz, quartz; Calc, calcite; Al, albite. Scale bar is $0.5 \mathrm{~mm}$.

alignments of K-feldspar. Pressure solution cleavages are frequently observed (Figure $9 \mathrm{f}$ ). The sense of shear is clearly indicated by asymmetric quartz ribbons (Figure 9e) and trails of feldspar recrystallized around K-feldspar clasts (Figure 9f). This microstructure is typical for Greenschist facies mylonitization. Albite and chlorite underline S1 schistosity planes and related mylonitic bands, which are distorted by late S2 plane.

[27] As previously underlined by Westercamp [1980], the Greenschist facies metamorphism is widespread in the entire La Désirade basement rocks. Even if kinetics of metamorphic transformations is higher in high strained zones (i.e., schistosity planes, discrete shear zones, fault zones) in relation with easy fluid infiltrations, metamorphic phases are also well developed as pseudomorphic associations replacing magmatic minerals in low strained rocks. This Greenschist facies metamorphism has been previously interpreted as ocean-floor hydrothermalism and/or to back arc-related metamorphism in relation with the dyke swarm complex emplacement during Oligocene [Westercamp, 1980; Maury et al., 1990]. Our observations support a radical revision of these interpretations. Indeed, the metamorphic phases are clearly syntectonic with respect to both D1 and D2 deformation episodes, and therefore the regional Greenschist facies metamorphism is contemporaneous with the thrust and related folds tectonics presently evidenced in this island.

\section{Age of Metamorphism and Deformation}

[28] Greenschist facies metamorphism is difficult to date because related metamorphic minerals are not available in classical geochronology. In order to approach the ages of the deformation, shear bands and/or fissure-filling syntectonic veins bearing K-rich minerals were investigated for $\mathrm{Ar}-\mathrm{Ar}$ geochronology.

[29] Adularia minerals were found in the northeast volcanic complex within a deformed zone oriented $20^{\circ} \mathrm{N} \pm 10^{\circ}$ and related to the second deformation event (D2, Figure 2; 
Table 1. Results of ${ }^{40} \mathrm{Ar} /{ }^{39} \mathrm{Ar}$ Measurements

\begin{tabular}{|c|c|c|c|c|}
\hline Incremental Heating & ${ }^{40} \mathrm{Ar}(\mathrm{rad})(\%)$ & ${ }^{39} \operatorname{Ar}(\mathrm{k})(\%)$ & ${ }^{40} \mathrm{Ar}(\mathrm{rad}) /{ }^{39} \mathrm{Ar}(\mathrm{k})$ & Age $\pm 2 \sigma(\mathrm{Ma})$ \\
\hline \multicolumn{5}{|c|}{ K258 Experiment, $J=0.0035309 \pm 0.5 \%(1 \sigma)$} \\
\hline Step 1 & 89.21 & 4.45 & 14.062630 & $87.43 \pm 5.08$ \\
\hline Step 2 & 97.30 & 6.74 & 15.644093 & $97.00 \pm 3.94$ \\
\hline Step 3 & 100.72 & 22.69 & 17.310957 & $107.03 \pm 2.60$ \\
\hline Step 4 & 101.31 & 9.26 & 17.348058 & $107.26 \pm 4.23$ \\
\hline Step 5 & 100.16 & 32.70 & 17.068859 & $105.58 \pm 2.46$ \\
\hline Fusion step & 98.19 & 24.14 & 17.056896 & $105.51 \pm 2.70$ \\
\hline Total fusion age & & & & $104.7 \pm 1.65$ \\
\hline Inverse isochron age & & & & $106.2 \pm 1.58$ \\
\hline \multicolumn{5}{|c|}{ K325 Experiment, $J=0.0035312 \pm 0.5 \%(1 \sigma)$} \\
\hline Step 1 & 72.21 & 11.98 & 17.541565 & $108.43 \pm 16.83$ \\
\hline Step 2 & 99.83 & 19.85 & 17.194043 & $106.34 \pm 2.41$ \\
\hline Step 3 & 99.83 & 21.52 & 17.498628 & $108.17 \pm 2.41$ \\
\hline Step 4 & 99.83 & 13.70 & 17.808073 & $110.02 \pm 2.85$ \\
\hline Step 5 & 99.83 & 14.51 & 17.339661 & $107.21 \pm 2.56$ \\
\hline Fusion step & 99.83 & 18.43 & 16.951980 & $104.88 \pm 2.53$ \\
\hline Total fusion age & & & & $107.3 \pm 2.48$ \\
\hline Inverse isochron age & & & & not defined \\
\hline
\end{tabular}

sample LV4), crosscutting the pillow lavas and the interbedded volcano-sedimentary units (Figure 6a). After heavy liquid separator to remove transparent crystals with $\mathrm{d}>$ $2.59 \mathrm{~g} / \mathrm{cm}^{3}$ (i.e., plagioclase and quartz crystals), adularia (125-200 $\mu \mathrm{m})$ were handpicked under a binocular microscope and were repeatedly cleaned ultrasonically in distilled water and leached with hot $\mathrm{HNO}_{3}(1 \mathrm{~N})$ for a few minutes. The crystals were coirradiated for $10 \mathrm{~h}$ in the nuclear reactor at the McMaster University in Hamilton (Canada), in position $5 \mathrm{c}$, along with Fish Canyon Sanidine monitor (28.03 Ma \pm $0.5 \%$ ) [Jourdan and Renne, 2007]. The ${ }^{40} \mathrm{Ar} /{ }^{39} \mathrm{Ar}$ analyses were performed at Geoazur laboratory. Adularia bulk samples (5 and 15 crystals for K258 and K325 step-heating experiments, respectively) were heated with a $\mathrm{CO}_{2}$ Synrad laser. The gas was purified in a stainless and glass extraction line using two $\mathrm{Al}-\mathrm{Zr}$ getters (working at $400^{\circ} \mathrm{C}$ and ambient temperature, respectively) and a liquid nitrogen cold trap. Isotopic measurements were performed with a VG3600 mass spectrometer and a Daly photomultiplier system. Blank measurements were obtained before and after every three sample runs (Table 1). The correction factors for interfering isotopes correspond to $\left({ }^{39} \mathrm{Ar} /{ }^{37} \mathrm{Ar}\right)_{\mathrm{Ca}}=(7.30 \pm 0.28) \times$ $10^{-4},\left({ }^{36} \mathrm{Ar} /{ }^{37} \mathrm{Ar}\right)_{\mathrm{Ca}}=(2.82 \pm 0.03) \times 10^{-4}$, and $\left({ }^{40} \mathrm{Ar} /{ }^{39} \mathrm{Ar}\right)_{\mathrm{K}}=$ $(2.97 \pm 0.06) \times 10^{-2}$. Ages were calculated using the decay constants of Steiger and Jäger [1977] and the air ${ }^{40} \mathrm{Ar} /{ }^{36} \mathrm{Ar}$ ratio of $298.56 \pm 0.1 \%$ (at $1 \sigma$ ) [Lee et al., 2006]. $J$ values range from $0.0035309 \pm 0.0000177(=0.5 \%$ at $1 \sigma)$ to $0.0035312 \pm 0.0000177(=0.5 \%$ at $1 \sigma)$. Mass discrimination values range from 1.00474 to $1.00738 \pm 1 \%(1 \sigma)$ per dalton (atomic mass unit). Detailed ${ }^{40} \mathrm{Ar} /{ }^{39} \mathrm{Ar}$ results are shown in Table 1 and age spectra in Figure 10.

[30] The two bulk samples of adularia yield well-defined and concordant plateau ages at $106.2 \pm 1.7 \mathrm{Ma}\left(89 \%{ }^{39} \mathrm{Ar}\right.$ released) and $107.2 \pm 1.8 \mathrm{Ma}\left(100 \%{ }^{39} \mathrm{Ar}\right.$ released $)$, respectively (Figure 4). The inverse isochron age for K325 experiment is not well constrained due to very small atmospheric gas fractions in plateau steps (initial ${ }^{40} \mathrm{Ar} /{ }^{36} \mathrm{Ar}$ intercept not well defined). For the $\mathrm{k} 258$ experiment, the inverse isochron age is concordant with the plateau age $(106.2 \pm 1.6 \mathrm{Ma})$. Thus, the weighted mean is $106.7 \pm 1.2$ Ma for the two bulk sample of adularia, suggesting a Lower Cretaceous (Albian) age for the D2 deformation event and thus for the end of the thickening/shortening tectonics in this area. Moreover, because the dykes are significantly metamorphosed under Greenschist facies conditions, the La Désirade dyke swarm complex cannot be anymore regarded as the product of the Late Eocene to Oligocene Lesser Antilles "old arc."

\section{Tectonic Evolution of La Désirade Basement in the Framework of Caribbean Geodynamics}

\subsection{Late Jurassic Position of La Désirade Island}

[31] Following our observations and chronological investigations, the magmatic basement of La Désirade Island was generated during Late Jurassic and shortened and metamorphosed during Lower Cretaceous. Plate reconstructions show that since Early Triassic the Pacific oceanic lithosphere, related to the Farallon plate, subducted toward east beneath North and South America and thus beneath the protoCaribbean oceanic crust. This subduction, at the protoCaribbean-Pacific boundary, generated island arc sequences including the Cretaceous "Great Arc" of the Caribbean [Burke et al., 1978; Burke, 1988, Oldow et al., 1989]. In this framework, the Late Jurassic ( 145 Ma) back-arc setting in which La Désirade could have initially formed was located to the east of the Andean/Cordilleran east-dipping subduction zone. La Désirade therefore formed logically in the proto-Caribbean realm (Figure 11a) and probably, as recently proposed by different authors, in the Colombian Marginal Seaway [Pindell and Kennan, 2009; Neill et al., 2010].

\subsection{Tectonic Evolution of La Désirade: A Key Aspect of Caribbean Geodynamics}

[32] The geological history of the La Désirade island needs now to integrate the progressive development of two episodes of compression, related to synmetamorphic (Greenschist facies) thrust tectonics, occurring during Albian times. Various models of geodynamic evolution of the Caribbean plate from Late Jurassic to Late Eocene are available [Pindell and Dewey, 1982; Burke, 1988; Pindell and Barrett, 1990; Gordon et al., 1997; Hutson et al., 1998; Sinton et al., 1998; Kerr et al., 1999, 2003; Schneider et al., 2004; Pindell and 

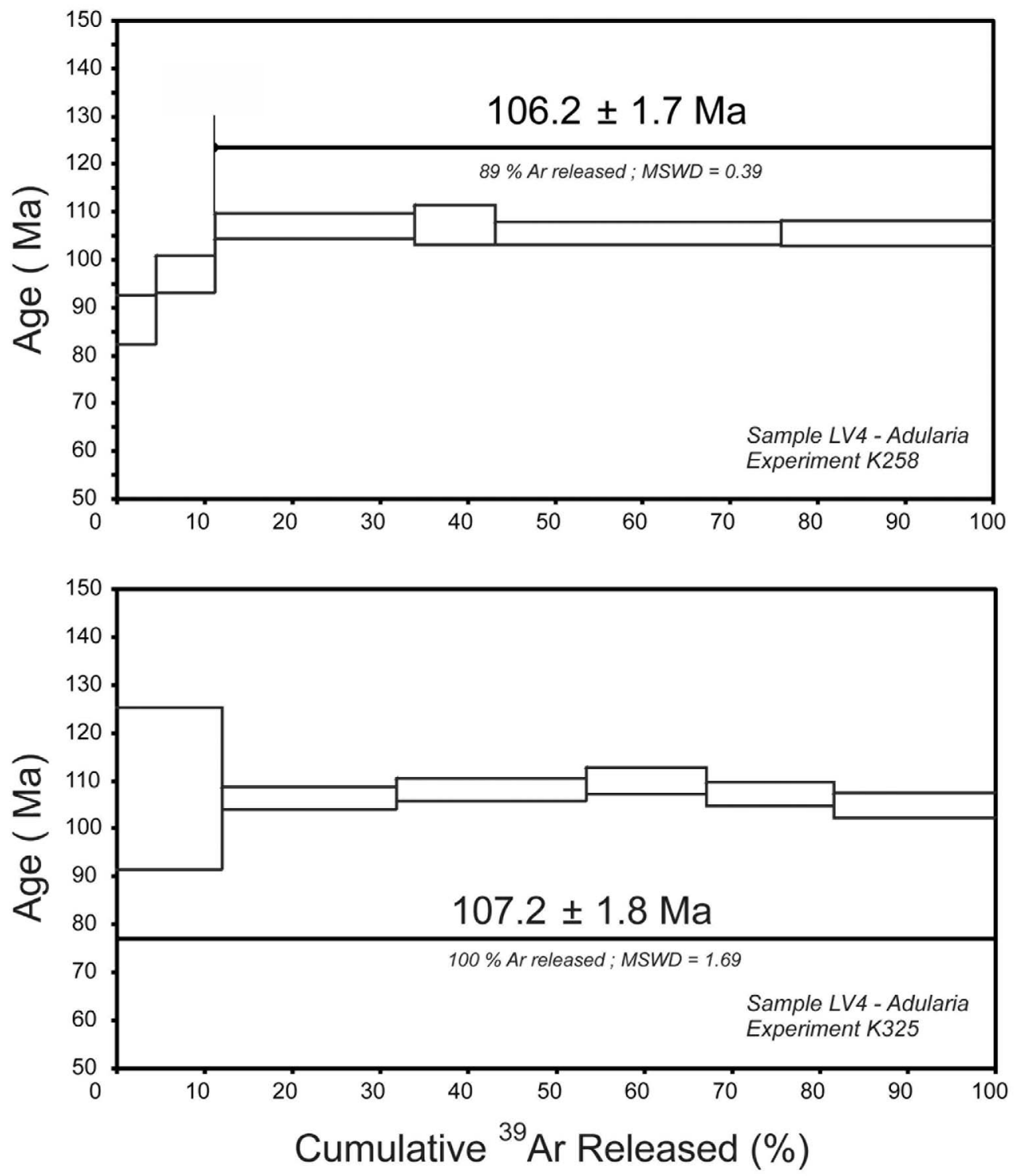

Figure 10. The ${ }^{40} \mathrm{Ar} /{ }^{39} \mathrm{Ar}$ age spectra as a function of ${ }^{39} \mathrm{Ar}$ released for the two experiments (K298 and K325). The error boxes of each step are at the $2 \sigma$ level. Error of the plateau ages is given at the $2 \sigma$ level. Ages were calculated using the Ar-Ar Calc program [Koppers, 2002]. MSWD for plateau and percentage of ${ }^{39} \mathrm{Ar}$ degassed used in the plateau calculation are indicated. Sample location is shown in Figures 2 and $6 \mathrm{a}$.

Kennan, 2009; Neill et al., 2010]. These models broadly agree on several important points.

[33] 1. North and South America separation as a consequence of the breakup of Pangaea to form oceanic crust by $\sim 160 \mathrm{Ma}$ in the Gulf of Mexico, proto-Caribbean and Colombian Marginal seaways.

[34] 2. Jurassic east-dipping oceanic subduction of the Pacific oceanic lithosphere beneath the proto-Caribbean oceanic crust and development of an arc system around the Jurassic-Cretaceous boundary, possibly along an older oceanic ridge located between the Pacific and proto-Caribbean plate. This arc gradually moved into the opening gap between North and South America.

[35] 3. Development of the Caribbean-Colombian Oceanic Plateau (CCOP) arriving in front of the Pacific subduction between Aptian to Santonien times. The eastward movement of the Farallon plate is responsible for the collision of the not readily subductable CCOP with the proto-Caribbean arc and continental northwestern South America.

[36] 4. The thickened nature $(\sim 8-20 \mathrm{~km})$ [Edgar et al., 1971; Case et al., 1990; Mauffret and Leroy, 1997] of the oceanic crust of the Caribbean plate and its probable Pacific origin. Their chemical and petrological compositions provide significant evidence that the Caribbean seafloor is in large part the remnant of the CCOP [Kerr et al., 2003].

[37] 5. The progressive insertion of the CCOP and/or a piece of Pacific crust between the two Americas induced compressive regime along the continental margins. From Campanian times, the Caribbean plate collided with both South and North America and moved east along transpressional boundaries into its present-day location. 

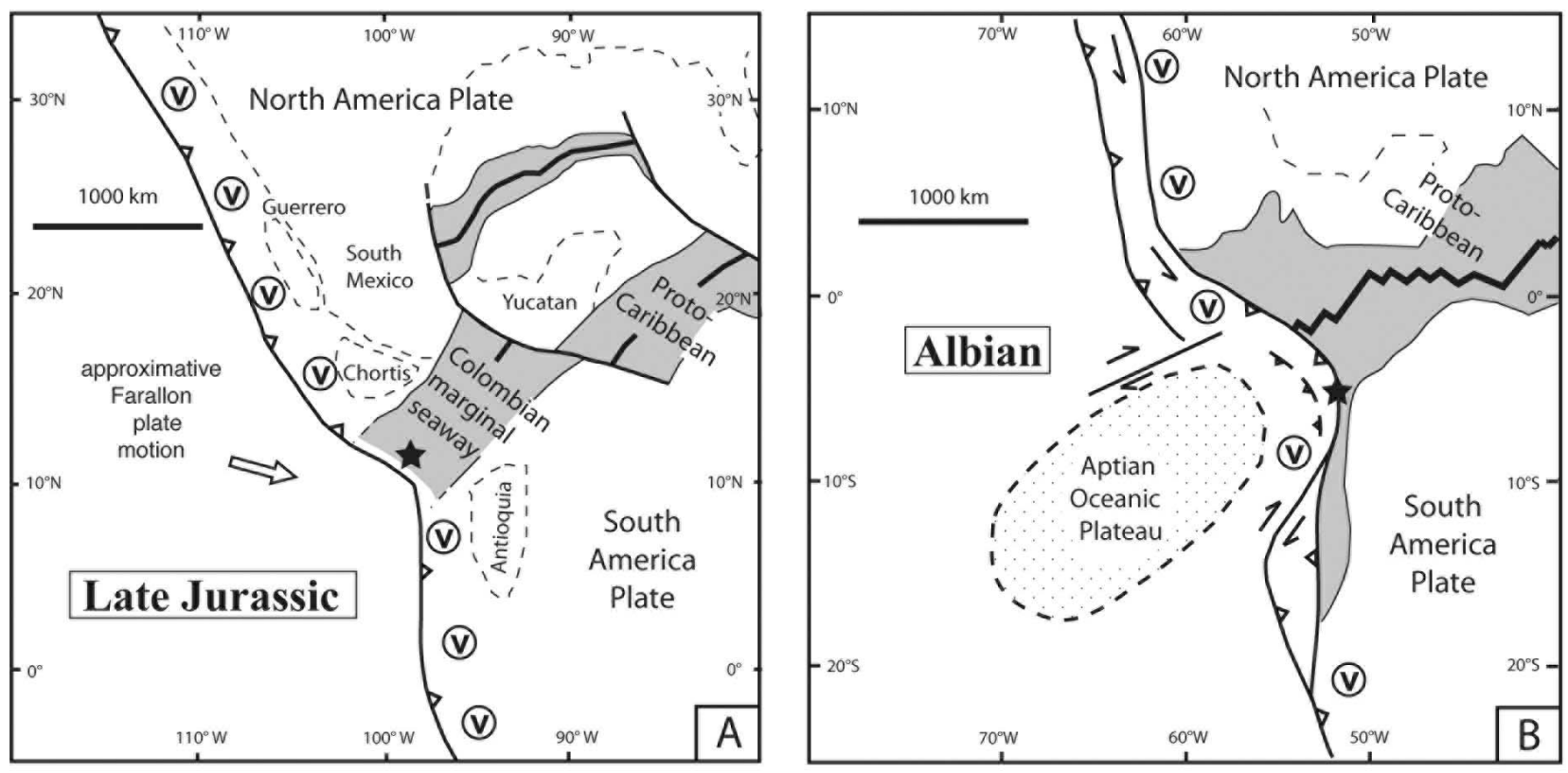

Figure 11. Geodynamic evolution of the Caribbean plate from (a) Late Jurassic to (b) Albian, modified after Pindell and Kennan [2009] and Neill et al. [2010].

[38] 6. Subduction polarity reversal, from eastward to westward dipping, which is required for the separation of the Caribbean plate from the Farallon plate.

[39] Nevertheless, within this consensus some of the problems that remain to be solved are (1) Is there one or several Pacific-derived plateau/island arc collision(s) in the Caribbean?; (2) What is the cause and the timing of the subduction polarity reversal?; and (3) Is the thickness of the Caribbean plate the result of only magmatic (i.e., mantle plume) activity?

[40] The various magmatic rocks of La Désirade have suffered severe transformations and deformations under Greenschist facies metamorphism of Albian age. The arc related acid igneous complex is overthrusted upon the ophiolitic complex under transpressive regime (D1 + D2 superposed events). A significant amount of shortening of the proto-Caribbean realm (i.e., Colombian Marginal Seaway) is therefore required, to produce the previously described finite strain pattern. Albian-Aptian time was one of major plateau-forming events in the Pacific [Mahoney et al., 1993; Kerr et al., 1997] and it is now widely accepted that the CCOP consists of material of broadly different ages: an Aptian age (124-112 Ma) phase, a 9183 Ma phase (the most voluminous) and a 78-72 Ma phase [Lapierre et al., 2000; Blein et al., 2003; Kerr et al., 2003]. We suggest that the synmetamorphic thrust tectonics, and related D1 and D2 fold systems, we discovered in La Désirade Island are a record of the collision of the early Pacific plateau against the island arc located at the protoCaribbean-Pacific boundary during Lower Cretaceous. This model is consistent with the occurrence of significant tectonic events at that time and with ages of exhumation of some of the Blueschist and Eclogite facies rocks described along the southern and northern Caribbean plate margins [Draper, 1986; Lebron and Perfit, 1994; Stöckhert et al.
1995; Pindell and Barrett, 1990; Sisson et al., 1997, 2003; Schneider et al., 2004; Tsujimori et al., 2005, 2006] This first tectonic accretion would be followed by the main collision between the 94-90 Ma years old CCOP and "Great Arc" of the Caribbean.

[41] Most Caribbean evolutionary models seemingly require a change in subduction polarity [Mattson, 1979; Pindell and Barrett, 1990; Jolly et al., 1998; Kerr et al., 1999, 2003; Pindell and Kennan, 2009], and two possible timings of polarity reversal have been proposed: Aptian-Albian times [Lebron and Perfit, 1994; Pindell et al., 2006; Pindell and Kennan, 2009] and Turonian-Santonian times [Burke, 1988; Sinton et al., 1998; White et al., 1999; Kerr et al., 1999, 2003]. Because, as recently suggested by Neill et al. [2010], in the framework of Caribbean geodynamics the initiation of southwest-dipping subduction occurred to the east of La Désirade, the tectonic evolution of the latter island is a key aspect of the polarity reversal event. In its present-day coordinates, the Albian thrust zone we discovered is characterized by kinematic indicators showing a top to the southeast sense of shear. This tectonic transport direction is compatible with a west-dipping subduction. Thus, with respect to the plate configuration in Lower Cretaceous [Geldmacher et al. 2008; Pindell and Kennan, 2009; Neill et al., 2010], we propose that collision of the Aptian oceanic plateau with the proto-Caribbean arc in the Albian is a possible mechanism for reversal in the polarity of subduction from east to west (Figure 11b). After this subduction flip and during the progressive eastward movement of the Caribbean plate, the Désirade magmatic basement evolved as a passive marker submitted to a rotation around $90^{\circ}$ to reach its present-day position (Figure 1).

[42] The Caribbean plate represents an area of overthickened oceanic crust because the Caribbean seafloor derives mainly from an oceanic plateau (i.e., the CCOP; see review by Kerr 
et al. [2003]). However, our discovery suggest that thrust tectonics may have played a significant role in the thickening of the Caribbean plate. La Désirade magmatic basement corresponds to the exhumed base of the active Lesser Antilles volcanic arc and our results demonstrate that the Lesser Antilles arc was emplaced on a previously thickened and folded oceanic crust under a transpressive regime. The Albian low-angle NW dipping thrust zone and the associated strike-slip ductile shear zones represent susceptible structures to be reactivated in the present-day tectonic regime and can account for strain partitioning and localization in the Lesser Antilles arc.

\section{Conclusions}

[43] We have come to the following conclusions.

[44] 1. A synmetamorphic thrust and related fold tectonics was recognized for the first time in La Désirade Island (French Lesser Antilles).

[45] 2. The Greenschist facies metamorphism was dated at around $106 \mathrm{Ma}$ (i.e., Albian).

[46] 3. This Lower Cretaceous tectono-metamorphic evolution records shortening/thickening processes in relation with the collision between an early (Aptian-Albian) Pacificderived oceanic plateau and the Andean/Cordilleran eastdipping subduction zone.

[47] 4. The tectonic evolution of La Désirade Island is compatible with subduction polarity reversal, from eastward to westward dipping, in the Lower Cretaceous.

\section{References}

Adamek, S., C. Frohlich, and W. D. Pennington (1988), Seismicity of the Caribbean-Nazca boundary: Constraints on microplate tectonics of the Panama region, J. Geophys. Res., 93, 2053-2075, doi:10.1029/ JB093iB03p02053.

Andreieff, P., G. Bizon, and P. Bouysse (1981), Révision de l'âge des formations sédimentaires de l'ile de Saint-Martin; Implications sur chronologie du volcanisme de l'arc insulaire des Petites Antilles: Paris, C. $R$. Seances Acad. Sci., Ser. 2, 25(6), 805-810.

Barrabé, L. (1953), Observations sur la constitution géologique de la Désirade, Bull. Soc. Geol. Fr., 6(3), 613-626.

Blein, O., S. Guillot, H. Lapierre, B. Mercier de Lépinay, J.-M. Lardeaux, G. Millan Trujillo, M. Campos, and A. Garcia (2003), Geochemistry of the Mabujina complex, central Cuba: Implications on the Cuban Cretaceous arc rocks, J. Geol., 111, 89-101, doi:10.1086/344666.

Bouysse, P. (1979), Caractères morphostructuraux et évolution géodynamique de l'arc insulaire des Petites Antilles (Campagne Arcante 1), Bull. Bur. Rech. Geol. Min. Fr., 2, 185-210.

Bouysse, P. (1988), Opening of the Grenada back-arc basin and evolution of the Caribbean Plate during the Mesozoic and early Paleogene, Tectonophysics, 149, 121-143, doi:10.1016/0040-1951(88)90122-9.

Bouysse, P., and D. Westercamp (1990), Subduction of Atlantic aseismic ridges and Late Cenozoic evolution of the Lesser Antilles island arc, Tectonophysics, 175, 349-380, doi:10.1016/0040-1951(90)90180-G.

Bouysse, P., R. Schmidt-Effing, and D. Westercamp (1983), La Desirade Island (Lesser Antilles) revisited: Lower Cretaceous radiolarian cherts and arguments against an ophiolitic origin for the basal complex, Geology, 11, 244-247, doi:10.1130/0091-7613(1983)11<244:LDILAR>2.0.CO;2.

Bouysse, P., P. Andreieff, M. Richard, J. C. Baubron, A. Mascle, R. C Maury, and D. Westercamp (1985), Aves Swell and northern Lesser Antilles Ridge: Rock-dredging results from Arcante 3 cruise, in Géodynamique des Caraïbes: Symposium, edited by A. Mascle, Ed. Technip, Paris.

Burke, K. (1988), Tectonic evolution of the Caribbean, Annu. Rev. Earth Planet. Sci., 16, 201-230, doi:10.1146/annurev.ea.16.050188.001221.

Burke, K., P. J. Fox, and A. M. C. Sengor (1978), Buoyant ocean floor and the evolution of the Caribbean, J. Geophys. Res., 83, 3949-3954, doi:10.1029/JB083iB08p03949.

Case, J. E., W. D. Mac Donald, and P. J. Fox (1990), Caribbean crustal provinces; Seismic and gravity evidence, in The Caribbean Region, vol. $H$,
The Geology of North America, edited by G. Dengo and J. E. Case, pp. 15-36, Geol. Soc. of Am., Boulder, Colo.

Cordey, F., and J. J. Cornée (2009), New radiolarian assemblages from La Désirade Island basement complex (Guadeloupe, Lesser Antilles arc) and Caribbean tectonic implications, Bull. Soc. Geol. Fr., 180(5), 399-409, doi:10.2113/gssgfbull.180.5.399.

Davidson, J. P., N. D. Boghossian, and M. Wilson (1993), The geochemistry of the igneous rock suite of St. Martin, Northern Lesser Antilles, J. Petrol., 34, 839-866.

DeMets, C., P. E. Jansma, G. S. Mattioli, T. H. Dixon, F. Farina, R. Bilham, E. Calais, and P. Mann (2000), GPS geodetic constraints on CaribbeanNorth America plate motion, Geophys. Res. Lett., 27, 437-440, doi:10.1029/1999GL005436.

Dinkelman, M. G., and J. F. Brown (1977), K-Ar geochronology and its significance to the geologic setting of La Desirade (Lesser Antilles), paper presented at 8th Caribbean Geological Conference, Willemstad, Curaçao, 9-12 Jul.

Dixon, H., and A. Mao (1997), A GPS estimate of relative motion between North and South America, Geophys. Res. Lett., 24, 535-538, doi:10.1029/97GL00284.

Dixon, T. H., F. Farina, C. DeMets, P. Jansma, P. Mann, and E Calais (1998), Relative motion between the Caribbean and North American plates and related boundary zone deformation from a decade of GPS observations, J. Geophys. Res., 103, 15,157-15,182, doi:10.1029/97JB03575.

Donnelly, T. W., et al. (1990), History and tectonic setting of Caribbean magmatism, in The Caribbean Region, vol. H, The Geology of North America, edited by G. Dengo and J. E. Case, pp. 339-350, Geol. Soc. of Am., Boulder, Colo.

Draper, G. (1986), Blueschists and associated rocks in eastern Jamaica and their significance for Cretaceous plate margin development in the northern Caribbean, Geol. Soc. Am. Bull., 97, 48-60, doi:10.1130/ 0016-7606(1986)97<48:BAARIE >2.0.CO;2.

Edgar, N. T., J. I. Ewing, and J. Hennion (1971), Seismic refraction and reflection in the Caribbean Sea, Am. Assoc. Pet. Geol. Bull., 55, 833-870.

Feuillet, N., I. Manighetti, and P. Tapponnier (2001), Active extension perpendicular to subduction in the Lesser Antilles island arc; Guadeloupe, French Antilles (in French), C. R. Acad. Sci., Ser. II, 333(9), 583-590.

Feuillet, N., I. Manighetti, P. Tapponnier, and E. Jacques (2002), Arc parallel extension and localization of volcanic complexes in Guadeloupe, Lesser Antilles, J. Geophys. Res., 107(B12), 2331, doi:10.1029/ 2001JB000308.

Fink, L. K., Jr. (1968), Marine geology of the Guadeloupe region, Lesser Antilles arc, Ph.D. thesis, 121 pp., Miami Univ., Miami, Fla.

Fink, L. K., Jr. (1970), Field guide to the island of La Desirade with notes on the regional history and development of the Lesser Antilles Island arc, in International Field Institute Guidebook to the Caribbean Island-Arc System, pp. 287-302, American Geol. Inst., Washington, D. C.

Fink, L. K., Jr. (1972), Bathymetric and geologic studies of the Guadeloupe region, Lesser Antilles island arc, Mar. Geol., 12, 267-288, doi:10.1016/ 0025-3227(72)90003-5.

Flinch, J., V. Rambaran, W. Ali, V. De Lisa, G. Hernandez, K. Rodrigues, and R. Sams (1999), Structure of Gulf of Paria pull-apart basin (eastern Venezuela-Trinidad), in Caribbean Basins, edited by P. Mann, pp. 477-494, Elsevier Sci, New York, doi:10.1016/S1874-5997(99)80051-3.

Fox, P. J., and B. C. Heezen (1975), Geology of the Caribbean crust, in The Ocean Basins and Margins, vol. 3, edited by A. E. M. Nairn and F. G. Stehli, pp. 421-466, Plenum, New York.

Gauchat, K. (2004), Geochemistry of Desirade Islands rocks (Guadeloupe, French Antilles), M.S. thesis, 80 pp., Univ. of Lausanne, Lausanne, Switzerland

Geldmacher, J., K. Hoernle, P. Van den Bogaard, F. Hauff, and A. Klügel (2008), Age and Geochemistry of the Central American Forearc Basement (DSDP Leg 67 and 84), Insights into Mesozoic Arc Volcanism and Seamount Accretion on the Fringe of the Caribbean LIP, J. Petrol., 49, 1781-1815, doi:10.1093/petrology/egn046.

Gordon, M. B., P. Mann, D. Cáceres, and R. Flores (1997), Cenozoic tectonic history of the North America-Caribbean plate boundary zone in western Cuba, J. Geophys. Res., 102(B5), 10,055-10,082, doi:10.1029/ 96JB03177.

Gunn, B. M., and M. J. Roobol (1976), Metasomatic alteration of the predominantly Island arc, Mar. Geol., 12, 267-288.

Hastie, A. R., and A. C. Kerr (2010), Mantle plume or slab window?: Physical and geochemical constraints on the origin of the Caribbean oceanic plateau, Earth Sci. Rev., 98, 283-293, doi:10.1016/j.earscirev.2009.11.001.

Heubeck, C., and P. Mann (1991), Geologic evaluation of plate kinematic models for the North America-Caribbean plate boundary zone, Tectonophysics, 191, 1-26, doi:10.1016/0040-1951(91)90230-P.

Holcombe, T. L., J. W. Ladd, G. Westbrook, T. Edgar, and C. L. Bowland 1990. Caribbean marine geology and basins of the plate interior, in The 
Caribbean Region, vol. H, The Geology of North America, edited by G. Dengo and J. E. Case, pp. 231-260, Geol. Soc. of Am., Boulder, Colo. Hutson, F., P. Mann, and P. Renne (1998), ${ }^{40} \mathrm{Ar} /{ }^{39} \mathrm{Ar}$ dating of single muscovite grains in Jurassic siliclastic rocks (San Cayentano Formation): Constraints on the paleoposition of western Cuba, Geology, 26, 83-86, doi:10.1130/0091-7613(1998)026<0083:AADOSM>2.3.CO;2.

Jolly, W. T., E. G. Lidiak, A. P. Dickin, and T. W. Wu (1998), Geochemical diversity of Mesozoic island arc tectonic blocks in eastern Puerto Rico, in Tectonics and Geochemistry of the Northeastern Caribbean, edited by E.G. Lidiak and D. K. Larue, Spec. Pap. Geol. Soc. Am., 322, $67-98$

Jordan, T. H. (1975), The present-day motions of the Caribbean plate, J. Geophys. Res., 80, 4433-4439, doi:10.1029/JB080i032p04433.

Jourdan, F., and P. R. Renne (2007), Age calibration of the Fish Canyon sanidine ${ }^{40} \mathrm{Ar} /{ }^{39} \mathrm{Ar}$ dating standard using primary $\mathrm{K}-\mathrm{Ar}$ standards, Geochim. Cosmochim. Acta, 71, 387-402, doi:10.1016/j.gca.2006.09.002.

Kerr, A. C., G. F. Marriner, J. Tarney, A. Nivia, A. D. Saunders, M. F. Thirlwall, and C. W. Sinton (1997), Cretaceous basaltic terranes in western Colombia: Elemental, chronological and $\mathrm{Sr}-\mathrm{Nd}$ isotopic constraints on petrogenesis, J. Petrol., 38, 677-702, doi:10.1093/petrology/ 38.6.677.

Kerr, A. C., J. Tarney, A. Nivia, G. F. Marriner, and A. D. Saunders (1998), The internal structure of oceanic plateaus: Inferences from obducted Cretaceous terranes in western Colombia and the Caribbean, Tectonophysics, 292, 173-188, doi:10.1016/S0040-1951(98)00067-5.

Kerr, A. C., M. A. Iturralde Vinent, A. D. Saunders, T. L. Babbs, and J. Tarney (1999), A new Plate tectonic model of the Caribbean: Implications from a geochemical reconnaissance of Cuban Mesozoic volcanic rocks, Geol. Soc. Am. Bull., 111, 1581-1599, doi:10.1130/0016-7606(1999) $111<1581:$ ANPTMO $>2.3 . \mathrm{CO} ; 2$

Kerr, A. C., R. V. White, P. M. E. Thompson, J. Tarney, and A. D. Saunders (2003), No oceanic plateau-No Caribbean plate? The seminal role of an oceanic plateau in Caribbean plate evolution, in The Circum-Gulf of Mexico and the Caribbean: Hydrocarbon Habitats, Basin Formation, and Plate Tectonics, edited by C. Bartolini, R. T. Buffler, and J. F. Blickwede, AAPG Mem., 79, 126-168.

Koppers, A. A. P. (2002), ArArCALC-Software for ${ }^{40} \mathrm{Ar} /{ }^{39} \mathrm{Ar}$ age calculations, Comput. Geosci., 28(5), 605-619, doi:10.1016/S0098-3004(01) 00095-4.

Lapierre, H., et al. (2000), Multiple plume events in the genesis of the periCaribbean Cretaceous oceanic plateau province, J. Geophys. Res., 105, 8403-8421, doi:10.1029/1998JB900091.

Le Guen de Kerneizon, M., A. Mascle, R. C. Maury, and D. Westercamp (1979), Les laves de La Désirade (Petites Antilles), témoins d'un magmatisme de marge active: Arguments minéralogiques, Bull. Bur. Rech. Geol. Min., Sect. 4, 3-4, 285-292.

Lebron, M. C., and M. R. Perfit (1994), Petrochemistry and tectonic significance of Cretaceous island-arc rocks, Cordillera Oriental, Dominican Republic, Tectonophysics, 229, 69-100, doi:10.1016/0040-1951(94) 90006-X.

Lee, J.-Y., K. Marti, J. P. Severinghaus, K. Kawamura, H.-S. Yoo, J. B Lee, and J. S. Kim (2006), A redetermination of the isotopic abundances of atmospheric Ar, Geochim. Cosmochim. Acta, 70(17), 4507-4512, doi:10.1016/j.gca.2006.06.1563.

Mahoney, J. J., M. Storey, R. A. Duncan, K. J. Spencer, and M. S. Pringle (1993), Geochemistry and geochronology of Leg 130 basement lavas: Nature and origin of the Ontong Java Plateau, in Ontong Java Plateau: Sites 803-807, Proc. Ocean Drill. Program Sci. Results, 130, 3-22.

Mann, P., F. W. Taylor, R. L. Edwards, and T. L. Ku (1995), Actively evolving microplatue formation by oblique collision and sideways motion along strike-slip fault: An example from the Northeastern Caribbean plate margin, Tectonophysics, 246, 1-69, doi:10.1016/0040-1951(94) 00268-E

Martin-Kaye, P. H. A. (1969), A summary of the geology of the Lesser Antilles, Overseas Geol. Miner. Resour., 10(2), 171-206.

Mascle, A., and P. Letouzey (1990), Geological Map of the Caribbean, Ed. Technip, Paris.

Mattinson, J. M., L. K. Fink Jr., and C. A. Hopson (1973), Age and origin of ophiolitic rocks on La Desirade Island, Lesser Antilles Island arc, Year Book Carnegie Inst. Washington, 72, 616-623.

Mattinson, J. M., L. K. Fink Jr., and C. A. Hopson (1980), Geochronologic and isotopic study of the La Desirade Island basement complex: Jurassic oceanic crust in the Lesser Antilles?, Contrib. Mineral. Petrol., 71, 237-245, doi:10.1007/BF00371665.

Mattinson, J. M., E. A. Pessagno Jr., H. Montgomery, and C. A. Hopson (2008), Late Jurassic age of oceanic basement at La Désirade Island, Lesser Antilles arc, in Ophiolites, Arcs, and Batholiths: A Tribute to Cliff Hopson, edited by J. Wright and J. Shervais, Spec. Pap. Geol. Soc. Am., $438,175-190$
Mattson, P. H. (1979), Subduction, buoyant braking, flipping, and strike-slip faulting in the northern Caribbean, J. Geol., 87, 293-304, doi:10.1086/ 628418 .

Mauffret, A., and S. Leroy (1997), Seismic stratigraphy and structure of the Caribbean igneous province, Tectonophysics, 283, 61-104, doi:10.1016/ S0040-1951(97)00103-0.

Maury, R. C., G. K. Westbrook, P. E. Baker, P. Bouysse, and D. Westercamp (1990) Geology of the Lesser Antilles, in The Caribbean Region, vol. H, The Geology of North America, edited by G. Dengo and J. E. Case, pp. 141-166, Geol. Soc. of Am., Boulder, Colo.

McCann, W. R., and L. R. Sykes (1984), Subduction of aseismic ridges beneath the Caribbean plate: Implications for the tectonics and seismic potential of the northeastern Caribbean, J. Geophys. Res., 89, 4493-4519, doi:10.1029/JB089iB06p04493.

Montgomery, H., E. A. Passagno, and Y. M. Munoz (1992), Jurassic (Tithonian) radiolaria from la Désirade (Lesser Antilles): Preliminary paleontological and tectonic implications, Tectonics, 11, 1426-1432, doi:10.1029/92TC01326.

Neill, I., J. A. Gibbs, A. R. Hastie, and A. C. Kerr (2010), Origin of the volcanic complexes of LaDésirade, Lesser Antilles: Implications for tectonic reconstruction of the Late Jurassic to Cretaceous Pacific-proto Caribbean margin, Lithos, 120, 407-420, doi:10.1016/j.lithos.2010.08.026.

Oldow, J. S., A. W. Bally, H. G. Avé Lallemant, and W. P. Leeman (1989), Phanerozoic évolution of the North American Cordillera, United States and Canada, in Geology of North America: An overview, vol. A, The Geology of North America, edited by A. W. Bally and A. R. Palmer, pp. 139-232, Geol. Soc. of Am., Boulder, Colo.

Pindell, J. L., and S. F. Barrett (1990), Geological evolution of the Caribbean region: A plate tectonic perspective, in The Caribbean Region, vol. H, The Geology of North America, edited by G. Dengo and J. E. Case, pp. 405-432, Geol. Soc. of Am., Boulder, Colo.

Pindell, J. L., and J. F. Dewey (1982), Permo-Triassic reconstruction of western Pangea and the evolution of the Gulf of Mexico/Caribbean region, Tectonics, 1, 179-211, doi:10.1029/TC001i002p00179.

Pindell, J. L., and L. Kennan (2009), Tectonic evolution of the Gulf of Mexico, Caribbean and northern South America in the mantle reference frame: An update, in The Origin and Evolution of the Caribbean Plate, edited by K. H. James, M. A. Lorente, J. L. Pindell, Geol. Soc. Spec. Publ., 328, 1-55.

Pindell, J. L., R. Higgs, and J. F. Dewey (1998), Cenozoic palinspastic reconstruction, paleogeographic evolution, and hydrocarbon setting of the northern margin of South America, in Paleogeographic Evolution and Non-Glacial Eustasy, Northern South America, edited by J. L. Pindell and C. L. Drake, Spec. Publ. SEPM Soc. Sediment. Geol., 58, 45-86.

Pindell, J. L., L. Kennan, K. P. Stanek, W. V. Maresch, and G. Draper (2006), Foundations of Gulf of Mexico and Caribbean evolution: Eight controversies resolved, Geol. Acta, 4, 89-128.

Schneider, J., D. Bosch, P. Monié, S. Guillot, A. Garíca-Casco, J. M. Lardeaux, R. Luís Torres-Roldán, and G. Millán Trujillo (2004), Origin and evolution of the Escambray Massif (Central Cuba): An example of HP/LT rocks exhumed during intraoceanic subduction, J. Metamorph. Geol., 22, 227-247, doi:10.1111/j.1525-1314.2004.00510.x.

Sinton, C. W., R. A. Duncan, M. Storey, J. Lewis, and J. J. Estrada (1998), An oceanic flood basalt province within the Caribbean plate, Earth Planet. Sci. Lett., 155, 221-235, doi:10.1016/S0012-821X(97)00214-8.

Sisson, V. B., I. E. Ertan, and H. G. A. Lallemant (1997), High pressure ( 200 MPa) kyanite- and glaucophane-bearing schist and eclogite from the Cordillera de la Costa belt, Venezuela. Implications for fluid mediated mass transfer in subduction zones and arc magma genesis, J. Petrol., 38, 65-83, doi:10.1093/petrology/38.1.65.

Sisson, V. B., G. E. Harlow, S. S. Sorensen, H. K. Brueckner, E. Sahm, S. Hemming, and H. G. Ave Lallemant (2003), Lawsonite eclogite and other high-pressure assemblages in the southern Motagua Fault zone, Guatemala: Implications for Chortís collision and subduction zones, Geol. Soc. Am. Abstr. Programs, 35, 639.

Steiger, R. H., and E. Jäger (1977), Subcommission on geochronology: Convention on the use of decay constants in geo- and cosmochronology, Earth Planet. Sci. Lett., 36, 359-362, doi:10.1016/0012-821X(77)90060-7.

Stöckhert, B., W. V. Maresch, M. Brix, C. Kaiser, A. Toetz, R. Kluge, and G. Kruckhans-Lueder (1995), Crustal history of Margarita Island (Venezuela) in detail: Constraint on the Caribbean Plate-tectonic scenario, Geology, 23, 787-790, doi:10.1130/0091-7613(1995)023<0787: CHOMIV $>2.3 . \mathrm{CO} ; 2$

Tsujimori, T., J. G. Liou, and R. G. Coleman (2005), Coexisting retrograde jadeite and omphacite in a jadeite-bearing lawsonite eclogite from the Motagua Fault Zone, Guatemala, Am. Mineral., 90, 836-842, doi:10.2138/am.2005.1699.

Tsujimori, T., V. B. Sisson, J. G. Liou, G. E. Harlow, and S. S. Sorensen (2006), Petrologic characterization of Guatemalan lawsonite eclogite 
Eclogitization of subducted oceanic crust in a cold subduction zone, in Ultrahighpressure Metamorphism: Deep Continental Subduction, edited by B. R. Hacker, W. C. McClelland, and J. G. Liou, Spec. Pap. Geol. Soc. Am., 403, 147-168.

Weber, J. C., T. H. Dion, C. DeMets, W. B. Ambeh, P. Jansma, G. Mattioli, J. Saleh, G. Sella, R. Bilham, and O. Perez (2001), GPS estimate of relative motion between the Caribbean and South American plates, and geologic implications for Trinidad and Venezuela, Geology, 29, 75-78, doi:10.1130/0091-7613(2001)029<0075:GEORMB >2.0.CO;2.

Westbrook, G. K., and W. R. McCann (1986), Subduction of Atlantic lithosphere beneath the Caribbean, in The Western North Atlantic Region, vol. M., The Geology of North America, edited by P. R. Voight and B. Tucholke, pp. 341-350, Geol. Soc. of Am., Boulder, Colo.

Westercamp, D. (1979), Diversité, controle structural et origines du volcanisme récent dans 1'arc insulaire des Petites Antilles, Bull. Bur. Rech. Geol. Min., Sect. 4, 3-4, 211-226.
Westercamp, D. (1980), Carte géologique de la Désirade à 1: 25000 et notice explicative, Serv. Geol. Nat., Bur. de Rech. Geol. Min, Orléans, France. White, R. V., J. Tarney, A. C. Kerr, A. D. Saunders, P. D. Kempton, M. S. Pringle, and G. T. Klaver (1999), Modification of an oceanic Plate, Aruba, Dutch Caribbean: Implications for the generation of continental crust, Lithos, 46, 43-68, doi:10.1016/S0024-4937(98)00061-9.

M. Balagne, Université Antilles-Guyane, IUT Campus de Saint-Claude, 97120 Saint-Claude, Guadeloupe.

M. Corsini, J. M. Lardeaux, and C. Verati, Université Nice-Sophia Antipolis, UMR Geoazur, Parc Valrose, F-06108 Nice, CEDEX 2, France. (corsini@unice.fr)

E. Voitus, Université Antilles-Guyane, IUFM de Guadeloupe, Morne Ferret, 97178 Abymes CEDEX, Guadeloupe. 